\title{
Who Compiled and Edited the Mashhad Miscellany?
}

\author{
LUKE TREADWELL \\ University of Oxford
}

(luke.treadwell@orinst.ox.ac.uk)

\begin{abstract}
The identity of the editors of the Mashhad miscellany generated considerable scholarly debate for a couple of decades after Togan's discovery of the Mashhad manuscript in 1923, but interest in the topic declined after the middle of the century. In the last seventy years, it is the miscellany's four texts, in particular the Kitāb of Ibn Fadlān, that have monopolized scholarly attention. This paper reopens the file on the mysterious editors in the belief that their role remains the key to understanding the majmu' 'a as well as its component texts. It reexamines the paratextual apparatus with which the editors framed the miscellany and concludes that the editors did not belong to the Mashriqi literary elite as earlier scholars maintained. The "editors" were in all probability not men of flesh and blood, but the fictional creations of the traveler, poet, and nadīm Abü Dulaf al-Khazrajī, author of the miscellany's two Risālas. His role as the mastermind of the Mash had miscellany compels us to reevaluate the miscellany's literary context and to think again about the provenance, structure, and contents of its four texts.
\end{abstract}

\section{Introduction}

Who compiled and edited the Mashhad miscellany? This question generated much scholarly interest for a couple of decades after Togan's discovery of the Mashhad manuscript in 1923. ${ }^{1}$ Two Russian historians, Krachkovskiǐ and Kovalevskiř, were particularly attentive to the issue in the first half of the twentieth century, but thereafter interest in the topic declined. The attempt to identify the miscellany's "editors" and understand their motivation seems to have reached an impasse in the middle of the century. At the same time, the rich complexities of the miscellany's constituent texts became increasingly evident as their

1. In this paper, the term "Mashhad manuscript" is used to refer to manuscript no. 5229 in the library of the Astane Quds shrine (i.e., the Imam Reza Shrine in Mashhad), which has been provisionally dated to the seventh/ thirteenth century, while the term "Mashhad miscellany" is applied to the compilation of texts (the majm $\bar{u}$ ca) that was assembled in the second half of the fourth/tenth century.

(c) 2020 Luke Treadwell. This is an open access article distributed under the terms of the Creative Commons Attribution-NonCommercial-NoDerivatives License, which allows users to copy and distribute the material in any medium or format in unadapted form only, for noncommercial purposes only, and only so long as attribution is given to the original authors and source. 
details were pored over, their language scrutinized, and their literary context elucidated. This paper will reopen the file on the two mysterious "editors," building on the insights produced by Russian scholarship and the remarks made by the few scholars (including Minorsky and Miquel) who have pursued the issue since. Although all contributors to the debate have had worthwhile points to make, as this study will demonstrate, none of the hitherto proposed reconstructions of the miscellany's genesis is compelling. To start afresh, I will return to Krachkovskiǐ and Kovalevskiǐ and reexamine their careful analysis of the paratextual apparatus with which the editors framed the miscellany. This apparatus includes both the introductory remarks with which they prefaced the miscellany's texts and the critical comments that they inserted in the Risālas of Abū Dulaf. The introductory remarks (henceforth referred to as the five "linking passages," or LPs), are the key to unlocking the identity and intentions of the person(s) who compiled the miscellany. As I will attempt to demonstrate, the editors were not, as earlier scholars have maintained, members of the Mashriqi literary elite but fictional creations of the real compiler and editor of the miscellany, Abū Dulaf al-Khazrajī, author of the miscellany's two Risālas. ${ }^{2}$

The argument that follows requires some background knowledge of the historiography, structure, and contents of the miscellany. I begin with an overview of the study of the Mashhad manuscript (Section 2), followed by a description of each of the texts (Section 3), a translation and analysis of the editorial linking passages (Sections 4 and 5), an examination of a unique and anomalous passage on the "towns of the Turks" at the end of Ibn al-Faqiih's book (Section 6), and, finally, some notes on the literary biography of Abū Dulaf al-Khazrajī.

\section{The Study of the Mashhad Manuscript}

In 1924, Zaki Velidi Togan published a note about an anonymous, acephalous manuscript in the library of the Imam Reza shrine in Mashhad that contained four texts. ${ }^{3}$ They included an extended version of the second half of Ibn al-Faqīh's Kitāb al-Buldān; ${ }^{4}$ two Risālas describing lengthy journeys, the first through Central Asia and al-Hind and the second across Iran, both undertaken by their author, Abū Dulaf al-Khazrajī; and the Kitāb of Ibn Faḍlān, the envoy who accompanied a caliphal mission from Baghdad to the court of the ruler of Bulghār on the River Volga in 309-10/921-23. ${ }^{5}$ The editors inform us that the Buldān was already a well-known text in Ibn al-Faqīh's lifetime, whereas the other three

2. In Sections 2-4 of this paper, frequent reference will be made to the (two) "editors" of the miscellany, whose identity modern scholars have investigated. From the final paragraph of Section 5 onward, reference will be made to Abū Dulaf as the editor of the miscellany.

3. A. Z. Validov (Togan), “Meshkhedskaya rukopis' Ibni-1'-Fakikha,” Izvestiia Rossǐ̌kǒ Akademii Nauk (1924): 237-48.

4. No manuscript of the book bears a title page or preface. Ibn al-Nadìm called the book Kitāb al-Buldān, while its title in the Mashhad manuscript is given as Kitāb Akhbār al-buldān; F. Sezgin et al., eds., Majmū'a fi al-jughrāfiyya: Mimmā allafahu Ibn al-Faqīh wa-Ibn Faḍlān wa-Abū Dulaf al-Khazrajī (Frankfurt: Ma'had Ta'rīkh al-'Ulūm al-'Arabiyya wa-1-Islāmiyya, 1987), 347.

5. For the purposes of clarity and brevity, the term Kitāb is applied to Ibn Faḍlān's text in this paper, while Abū Dulaf's texts are referred to as the first and second Risālas and Ibn al-Faqīh's book as the (Kitāb Akhbār al-) Buldān. 
texts were by unknown authors (see Section 4). Both the Kitāb and the Risālas were heavily cited by Yāqūt al-Hamawī (d. 626/1229) in his voluminous gazetteer of the Islamic world,

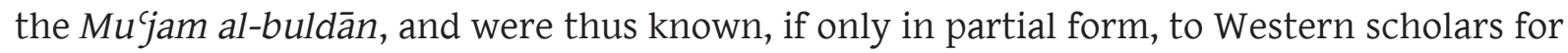
several decades before the publication of the Mashhad manuscript. ${ }^{6}$

Of the four texts, Ibn Faḍlān's Kitāb has received the lion's share of attention since Togan's discovery. Togan himself published the first major study in 1939, the same year in which Krachkovskil published a commentary and translation, alongside a facsimile reproduction of the text itself. ${ }^{7}$ In his commentary, Krachkovskil made an observation that is crucial to the argument presented in this paper: he pointed out that the editors of the miscellany were identical with the two patrons to whom Abū Dulaf sent copies of his Risālas. ${ }^{8}$ The editors wrote short introductions to the Risālas in which they cited Abu Dulaf's dedicatory prefaces. They also inserted several critical comments in the texts of the Risālas in which they expressed doubts about the reliability of certain passages in his account (see below, Section 3). A third translation of and comprehensive commentary on the Kitāb was written by Kovalevskil in $1959 .{ }^{9}$ Since that date, many new translations have appeared in several languages, as well as a great many academic papers on the literary aspects of the Kitāb, the personality and background of its author, the political context of his mission, and the wider context of premodern travel literature within which his travelogue should be read. ${ }^{10}$

The publication of the miscellany spurred interest in Abū Dulaf's texts as well, even if at a slower rate, yielding editions and translations of both his Risālas, but fewer studies. ${ }^{11}$

6. Yāqūt, Mu'jam al-buldān (Beirut: Dār Șādir, n.d.).

7. Z. V. Togan, Ibn Fạ̣lān's Reisebericht (Leipzig: Brockhaus, 1939); I. Yu. Krachkovskiľ, Puteshestvie Ibn-Faụlāna na Volgu (perevod i kommentariǐ) (Moscow: Izdatelstvo Akademii Nauk SSSR, 1939). Ritter stated, without giving his sources, that Kovalevskiǐ was the author of the translation and commentary that appeared under Krachkovskiî's name in 1939; see H. Ritter, “Zum Text von Ibn Faụlān's Reisebericht," Zeitschrift der Deutschen Morgenländischen Gesellschaft 9 (1942): 98-99.

8. In reference to the first Risāla, the editors write (in LP3), kataba ilaynā Abū Dulaf ... fi dhikr mā shāhadahu wa-ra'āhu fi balad al-Turk wa-l-Hind wa-1-Șin ("Abū Dulaf wrote to us mentioning what he witnessed and saw in the lands of the Turk, India, and China"); see Section 4.

9. A. P. Kovaleskiľ, Kniga Akhmeda ibn-Faḍlāna o ego puteshestvii na Volgu v. 921-922 gg. (stat'i, perevody $i$ kommentarii) (Kharkov: Izdatelstvo Gos. Universiteta im. A. M. Gori’kogo, 1956).

10. For a convenient summary of the literature, see J. E. Montgomery, "Mission to the Volga," in Two Arabic Travel Books, ed. P. F. Kennedy and S. M. Toorawa (New York: New York University Press, 2014), 285-297 ("Further Reading"). See also the forthcoming publication of the papers of a conference on Ibn Faḍlān held in Oxford in 2016: J. Shepard and W. L. Treadwell, eds., Muslims on the Volga:Diplomacy and Islam in the World of Ibn Faḍāan (London: I. B. Tauris, 2021) and the catalogue of a major exhibition organized in Kazan published as A. I. Torgoev, ed., Puteshestvie Ibn Faḍlāna: Volzhskiǐ put' ot Bagdada do Bulgara (Moscow: Dom Mardzhani, 2016).

11. For a German translation of and commentary on the first Risāla, see A. von Rohr-Sauer, Des Abū Dulaf Bericht über seine Reise nach Turkestān, China und Indien: Neu übersetzt und untersucht (Bonn: Bonner Universitäts Buchdruckerei, 1939); for an edition and annotated English translation of the second Risāla, see V. Minorsky, Abū Dulaf Miṣ 'ar ibn Muhalhil's Travels in Iran (circa A.D. 950) (Cairo: Cairo University Press, 1955). For an edition and annotated Russian translation of the second Risāla, see P. G. Bulgakov, Vtoraya zapiska Abu Dulafa (Moscow: Izdatelstvo Vostochnor̆ Literatury, 1960); for articles on the second Risāla, see I. Yu. Krachkovskǐ̌, "Vtoraya zapiska Abū Dulafa v geograficheskom slovare Iāḳūta (Azerbaǐzhan, Armeniya, Iran)," 
Abū Dulaf's travelogues did not hold the same allure for modern readers as Ibn Faḍlān's narrative did, being uneven in style and lacking the immediacy of the first-person voice and the minute attention to the behaviors of steppe peoples that make the latter's account such a riveting read. Abū Dulaf's first Risāla has long been perceived to be a caricature of the travel genre (see Section 3), ${ }^{12}$ although the second Risāla has attracted less criticism. On the whole, however, whereas Ibn Faḍlān has become a star of Arabic literature, particularly in twenty-first-century scholarship, Abū Dulaf has been largely neglected over the past half century. As for Ibn al-Faqiih, whose text opens the miscellany and takes up the bulk of the manuscript, difficulties in gaining access to a reproduction of the whole manuscript, as well as the evident disorder among the disbound folios of the manuscript, were noted by Pellat in 1973 in his foreword to the posthumous publication of Massé's French translation of the abridged version of the work. ${ }^{13} \mathrm{~A}$ facsimile edition of the manuscript eventually appeared under the supervision of Fuat Sezgin in 1987 (which, however, omitted the crucial first folio of the manuscript). ${ }^{14}$ An edition of the whole of Ibn al-Faqih's work, which combines de Goeje's abridged edition and the version in the Mashhad manuscript, was published by Yūsuf al-Hādī in 2009.15

\section{Description of the Texts in the Miscellany}

The first text, which is the second part of Ibn al-Faqīh al-Hamadhānī's Kitāb al-Buldān, is by far the longest of the four. ${ }^{16}$ It comprises an extended version of Ibn al-Faqīh's book, which is otherwise known only from de Goeje's abridged edition. Supplementary information supplied by this text, not present in the Mukhtașar, includes additional chapters on Wāșiț, Nabațiyya, Baghdad, Samarra, the Sawād, al-Ahwāz, the kharāj of Khurasan, the Turks, and the titles of the Turks and their neighbors in the Mashriq. ${ }^{17}$ The miscellany's text may have been the second of two volumes prepared by the editors, the first volume having contained Ibn al-Faqih's material on the western Islamic world (the Maghrib), but no trace of the first volume has ever been found. ${ }^{18}$

Izvestiia Akademii Nauk Azerbaizhanskoi SSR 8 (1949): 65-77, repr. in Izbrannye sochineniia, ed. V. I. Beliaev and G. V. Tsereteli, 6 vols., 1:280-92 (Moscow: Izdatelstvo Akademii Nauk SSSR, 1955), and V. Minorsky, "La deuxième risāla d'Abū-Dulaf," Oriens 5, no. 1 (1952): 23-27.

12. See, for example, A. Miquel, La géographie humaine du monde musulman jusqu'au milieu du 11e siècle (Paris: Éditions de l'EHESS, 2001), 3:139-45.

13. H. Massé, trans., Abrégé du livre du pays (Damascus: Institut français de Damas, 1973), vi-vii; Ibn al-Faqīh, Mukhtașar kitāb al-Buldān, ed. M. J. de Goeje (Leiden: Brill, 1885).

14. Sezgin, Majmūca. For an image of the missing first folio, see the final page of this paper.

15. Ib̉n al-Faqīh, Kitāb al-Buldān, ed. Y. Al-Hādī, 2nd ed. (Beirut: 'Ālam al-Kutub, 2009).

16. It takes up 347 pages in Sezgin's facsimile (Sezgin, Majmū`a).

17. For a summary of the differences between the two versions of the Buldān, see A. B. Khalidov, "Ebn al-Faqīh, Abū Bakr Aḥmad," in Encyclopaedia Iranica, online ed., updated 2011.

18. The first line of the book begins Hādha baqiyyat al-qawl fi al- Irāq ... ("This is what remains to be said about Iraq ..."); see LP1 in Section 4. This phrase could mean that the "remainder" referred to is the second part of the book, which followed an earlier volume on the Maghrib. Alternatively, the reference to "what remains" could conceivably have been to the extra information contained in the miscellany's version that supplemented 
The three other texts in the miscellany are much shorter than the Buldān. They are not geographies but rather travelogues whose authors claim to have traveled through the regions that they describe. Abū Dulaf's first Risāla tells the story of his journey to the court of the King of "China" (al-Șin, probably the Uighur ruler of Qocho) in the company of an embassy that was dispatched in 330/941 by the Samanid amir Nașr II (r. 301-31/913-42) to escort the king's daughter back to Bukhara, where she was to marry Nașr's son. ${ }^{19}$ The journey begins with brief descriptions of the social, political, and dietary conditions of the Central Asian tribes through whose territory he passed, before his arrival in the capital city of Sandābill, which he describes as a great walled conurbation crisscrossed by canals with windmills on their banks. The tribes are succinctly described in formulaic terms, often with a deliberate inflection toward parody. Although he narrates his journey in the first person, Abū Dulaf does not write about his own experience of the journey or his personal encounters with the Turks. In Sandābill, the author claims to have met the king and answered his questions about the Dār al-Islām, but he then left the embassy and returned to Bukhara by himself via the Malay peninsula, India, Sind, and Sistan. Both the outward and return legs of his journey follow implausibly long and circuitous routes that frequently zigzag and backtrack across the regions they cover, some deviations adding several extra hundred kilometres to the journey for no discernible purpose. The description of the return journey is looser and less stylistically homogeneous than his earlier account of the Turkish territories, including quite extensive comments on mineralogy and flora, as well as remarks on towns and their buildings and the monetary and sartorial customs of their residents. Although less obviously a parody than the outward leg, the return journey is full of tall tales and unlikely assertions and has been described as a mishmash of materials borrowed from unnamed sources. ${ }^{20}$

The second Risāla describes a journey that takes the narrator all over the southern Caucasus on a meandering route from Takht-i Sulaymān to Tiflis to Ardabil to Erzurum and then to Khānaqīn, whence he sets out on an easterly course that takes him across the Iranian plateau to Tus. From there he returns in a southwesterly direction, finishing up in al-Ahwāz. The reason for the journey is not given and the narrator is barely present in the text, even though he occasionally makes comments in the first person. The text contains frequent references to mineralogy and flora and reveals the author's interest in folktales and popular interpretations of natural phenomena, as well as his curiosity about ancient buildings of the Sasanian era. On the whole, the "journey" sounds more like a compilation of field notes than a description of a traveled road. ${ }^{21}$

Both Risālas are notable for their inclusion of several critical comments written by the editors, two of them in the first and three in the second Risāla. The following table lists the comments.

an abridged version, which was probably similar to the Mukhtașar edited by de Goeje.

19. See W. L. Treadwell, A History of the Sāmānids: The First Islamic Dynasty of Central Asia (Edinburgh: Edinburgh University Press, forthcoming in 2021), for the identification of Sandābill with Qocho.

20. Miquel, Géographie humaine 3:140, n. 4.

21. See Minorsky, Travels in Iran, for a detailed commentary on the second Risāla. 
Table 1: Critical comments inserted in the Risālas by the editors.

\begin{tabular}{|c|c|c|c|}
\hline $\begin{array}{l}\text { Comment } \\
\text { No. }\end{array}$ & Risāla & $\begin{array}{l}\text { Page No. in Sezgin's } \\
\text { Facsimile }\end{array}$ & Text to Which the Critical Comment Relates \\
\hline 1 & First Risāla & $356\left(M u^{c} j a m\right.$ 3:445) & $\begin{array}{l}\text { Description of the funeral of the Samanid amir, } \\
\text { Nașr II, the date of whose death was foretold at } \\
\text { birth. On the appointed day, Nașr proceeded with } \\
\text { his notables and household to his tomb, entered it, } \\
\text { and died therein. }\end{array}$ \\
\hline 2 & First Risāla & $361\left(M u^{c} j a m\right.$ 3:447) & $\begin{array}{l}\text { The height of the idol in the temple of Multān, } \\
\text { which Abū Dulaf gives as one hundred cubits. }\end{array}$ \\
\hline 3 & Second Risāla & $\begin{array}{l}363 \text { (Travels in } \\
\text { Iran, 2) }\end{array}$ & $\begin{array}{l}\text { A report on the fire temple in Shìz near Marāgha, } \\
\text { on the dome of which there was a silver crescent. }\end{array}$ \\
\hline 4 & Second Risāla & $\begin{array}{l}374(\text { Travels in } \\
\text { Iran, } 14)\end{array}$ & $\begin{array}{l}\text { A building plot in Qarmīsin, which, when excavated, } \\
\text { revealed the remains of an older construction that } \\
\text { exactly matched the plan of the new house that was } \\
\text { to be built on the site. }\end{array}$ \\
\hline 5 & Second Risāla & $\begin{array}{l}379-80(\text { Travels in } \\
\text { Iran, 20) }\end{array}$ & $\begin{array}{l}\text { A prosperous and generous Zoroastrian purveyor } \\
\text { of supplies to the army of Rayy who never refused } \\
\text { anyone who asked him for wine. }\end{array}$ \\
\hline
\end{tabular}

Comment no. 1: After the description of Nașr's funeral, which follows the story of the daughter of the Uighur king who was brought to Bukhara as a bride for Nașr's son, the editors state that they doubt the truth of this passage. They explain that their informant, the author (Abū Dulaf), "occasionally mentioned something for which he asked God not to take him to account/blame him." ${ }^{23}$

Comment no. 2: The editors dismiss Abū Dulaf's figure of one hundred cubits for the height of the idol in favor of the lower figure of twenty cubits given by al-Madāinin in his Futūh al-Sind wa-l-Hind. ${ }^{24}$

22. Reference is also made (in brackets) to Yāqūt's Mucjam (first Risāla) and the Arabic text of Minorsky's Travels in Iran (second Risāla).

23. For the clearest version of the text, which is obscured by copyist's errors in the Mashhad manuscript, see Yāqūt's Mu 'jam, 3:452: Naḥnu nashukku fị șịhhat hādhā al-khabar li-anna muḥaddithanā bihi rubbamā kāna dhakara shay’an fa-sa'ala Allāha an lā yu’ākhidhahu bi-mā qāla.The story of Nașr's entombment may have been a popular tale that grew up around the construction of the famous Samanid mausoleum in Bukhara, said to have been built by Nașr to house the remains of his grandfather Ismā'īl b. Aḥmad (d. 295/907) and to have served as his own shrine as well. See S. Blair, The Monumental Inscriptions from Early Islamic Iran and Transoxiana (Leiden: Brill, 1991), 25-29.

24. The editors state, again, Nashukku fi șịhhat hādhā al-khabar ("We doubt the truth of this report"). 
Comment no. 3: The editors brand Abū Dulaf's description of the fire temple an exaggeration, although it is not entirely clear which part of the description has prompted their criticism. ${ }^{25}$

Comment no. 4: The editors express their skepticism about the claimed resemblance between the uncovered remains of the old building and the new building. ${ }^{26}$

Comment no. 5: The editors dismiss the account of the extreme generosity of the provisions merchant as another of Abū Dulaf's inventions. ${ }^{27}$

These editorial interventions are puzzling. The editors made no comments on the texts of Ibn al-Faqīh and Ibn Faḍlān; why should they have chosen to comment only on the work of their protégé? It is also curious that the editors retained their comments in the text of the Risālas when they had them copied into the miscellany. Of what benefit to the reader did they expect their critical comments to be? Moreover, it is interesting to note that Abu Dulaf himself was aware of his own reputation for hyperbole: after a note on the enormous size of the rhubarb plants he saw when in the city of Nishapur, he wrote, "My readers will take this for an exaggeration on my part, but I have stated only what I have witnessed and seen." ${ }^{28}$ It is as though Abū Dulaf was presciently aware of the editors' sensitivity about his tendency to be economical with the truth-yet how could this have been so, given that when he wrote this remark, he cannot have been apprised of the editors' intention to expose him?

Taken all together, the editors' criticisms, though robust, are not entirely damning of Abū Dulaf's credibility. They are focused on five rather marginal points, none of which is integral to the core of Abū Dulaf's narrative. At the same time, the editors are silent about glaring lapses in narrative objectivity, such as Abū Dulaf's description of the Turkish tribes at the beginning of the first Risāla. I return to these conundrums when I discuss the question of the editors' identity (see Section 5).

Ibn Faḍlān's narrative stands in marked contrast to the Risālas. The scene is set with a presentation of the dramatis personae who organized and took part in the mission to the court of the Bulghār king. From the moment the embassy sets out from the capital, the reader has the sense that the author really did experience the discomforts of the road, the harshness of the climate, and the fears and exhilaration of traveling in unknown regions. ${ }^{29}$ The text, like Abū Dulaf's first Risāla, falls into two parts. The first is the record of Ibn Faḍlān's journey from Baghdad to Bulghār, which is clearly marked by the stopping points where the embassy alighted, and punctuated by encounters with Nașr II and the

25. The editors remark, Wa-hādhā al-qawl ayḍan min ziyādāt Abī Dulaf ("This statement is also one of Abū Dulaf's exaggerations").

26. The editors write, Wa-hādhā al-khabar ayḍan naẓunnuhu min wahm Abī Dulaf ("We consider this report, too, to be one of Abū Dulaf's fancies").

27. Wa-hādhā al-khabar naẓunnuhu aỵ̣an ba'ḍa hānāt Abī Dulaf ("We also consider this report one of Abū Dulaf's whimsies").

28. Wa-yasta'zimu hādhā min qawlī man yasma'uhu wa-mā qultu illā mā shāhadtu wa-ra’aytu; Minorsky, Travels in Iran, Ar. text 27; trans., 59-60 = Sezgin, Majmū ‘a, 386.

29. See Miquel, Géographie humaine, 3:138. 
Khwārazmshāh. It is full of sharply observed remarks on the Turkic peoples the author encountered en route, particularly the Ghuzz chiefs to whom the envoys delivered messages from the Abbasid court. ${ }^{30}$

Once in Bulghār, the envoys endured two unsettling and intimidating audiences with the king, who scolded them for failing to deliver the funds he had been assured he would receive from the caliph. After the meetings with their host, the story of the embassy comes to an end; thereafter the reader hears nothing about the mission's fate and is left to assume, given their initial reception, that it was not a happy one. The second part of the Kitāb presents twenty-two "marvels" ('ajāib) that Ibn Faḍlān witnessed in Bulghār, where he must have remained for a while after meeting the king. These marvels are mostly not "wonders" in the sense of unbelievable occurrences, but rather accounts of the customs and practices of the Turkic peoples and the Rus' merchants who traded with them, as well as various natural phenomena-faunal, floral, and meteorological. ${ }^{31}$ Although the text of the Mashhad manuscript ends abruptly a few lines into the final section, which is on the Khazars, Yāqūt supplies the full text of Ibn Faḍlān's final entry in his Mújam. ${ }^{32}$ Unlike Abū Dulaf, Ibn Faḍlān seems not to have written about his return journey, although Yāqūt states several times that he did return to the Abbasid capital. ${ }^{33}$

Ibn Faḍlān's Kitāb has been much discussed over the past century and a half. Prior to the discovery of the Mashhad manuscript, scholarly opinion had been divided between skeptics such as Marquart, who believed that Ibn Faḍlān had never traveled to Bulghār, and others who were persuaded that he had indeed experienced what he wrote about. ${ }^{34}$ After the full version of the text in the miscellany was published, most scholars accepted as credible Ibn Faḍlān's claim to have experienced firsthand what he recorded in the Kitāb. Doubts persisted, however, over some aspects of his account and the difficulty of pinpointing exactly why and where the Kitāb had been written. The internal structure of the narrative, the structural disjunction between the first and second parts of the narrative, the occasional abrupt change of subject matter, the apparent truncation of the text, and an unsettling "doppler" or "echo" effect, which results in similar observations being recorded of different peoples-such anomalies and inconsistencies, together with the author's absence from the historical record and the lack of interest shown by contemporary authors in his text,

30. Montgomery, "Mission to the Volga," 210-11.

31. See J. E. Montgomery, "Travelling Autopsies: Ibn Faḍlān and the Bulghār," Middle Eastern Literatures 7, no. 1 (2004): 3-32.

32. For the full text, see Togan, Reisebericht, 43-45 (Arabic text). See also J. E. Montgomery, "Where Is the Real Ibn Faḍlān?," in Shepard and Treadwell, eds., Muslims on the Volga.

33. Yāqūt prefaces several of the entries in the Mu'jam that he extracted from Ibn Faḍlān's text with the following sentence (and variations thereof): Qara'tu risālatan 'amilahā Aḥmad b. Faḍlān ... rasūl al-Muqtadir bi-llāh ... dhakara fihā mā shāhadahu mundhu infașala min Baghdād ilā an 'āda ilayhā ("I read an epistle written by Ahmad b. Faḍlān ... the envoy of al-Muqtadir bi-1lāh ... in which he recorded what he witnessed from the time he left Baghdad to the time that he returned to the city"); Yāqūt, Mújam, 1:486, entry on "Bulghār." See also Yāqūt's entries on the Bāshghird (1:322), Khwārazm (2:397), and the Rūs' (3:79).

34. Kovalevskiı̌, Kniga, 39. 
continue to nourish doubts about the veracity of the account. ${ }^{35}$ In recent decades, however, the Kitāb has been hailed by medievalists from different disciplines for the light it throws on the steppe peoples and for the insights it provides into the ethnic composition of the early Rus'. Confidence in the reliability of the information provided by Ibn Faḍlān continues to grow, as some of his more bizarre observations have been corroborated by recently discovered archaeological and ethnographic data, ${ }^{36}$ while doubts about the narrative's structure and the context of its production have faded into the background. Ibn Fac̣lān's account has even been praised as a rare example of the art of reportage in early Arabic literature..$^{37}$ Ibn Faḍlān has become, in the eyes of many modern readers, a heroic figure, who is celebrated not only for his exceptional skill as a social observer and his dogged and impartial recording of what he saw but also for his quiet endurance of adversity and his human qualities. ${ }^{38}$

\section{The Compilation of the Miscellany and the Editorial "Linking Passages"}

In the decades after the discovery of the Mashhad manuscript, Russian scholars paid close attention to the question of the editors' identity and their reasons for compiling the miscellany. ${ }^{39}$ Kovalevskil addressed the question of how and where the Kitāb and the Risālas were written and how these texts came into the possession of the editors. ${ }^{40}$ In his view, both Ibn Faḍlān and Abū Dulaf wrote their texts in Iraq. Kovalevskiľ accepts Yāqūt's statement that Ibn Faḍlān returned from Bulghār to Baghdad and assumes that the Kitāb was written as an official report shortly afterward. A copy of the report found its way (by means unexplained) to Bukhara, where it came into the possession of two erudite noblemen. Abū Dulaf, for his part, presented his Risālas to the famous Buyid vizier al-Ṣāhiib b. 'Abbād at some time early in the second half of the fourth/tenth century, a full three decades or more after Ibn Faḍlān had written the Kitāb. ${ }^{41}$ His Risālas, like the Kitāb, also ended up in Bukhara: Abū Dulaf sent copies of them to former patrons of his in the city, who happened to be the very same noblemen who had earlier come into possession of Ibn Faḍlān's Kitāb. At some point in the second half of the fourth/tenth century, these two Bukharan noblemen-

35. For an analysis of these problems, see W. L. Treadwell, "Ibn Faḍlān and the Mashhad Miscellany" (forthcoming).

36. See J.-C. Ducène, L'Europe et les géographes arabes du Moyen Âge (Paris: CNRS Éditions, 2017), 139-40, for a summary of the corroborating evidence for Ibn Faḍlān's description of the funeral of the Rus' chief.

37. See a translation of the funeral of the Rus' chief in J. Carey, ed., Faber Book of Reportage (London: Faber, 1989), 25-28.

38. See, e.g., the introduction to Montgomery, "Mission to the Volga," 171: "I find Ibn Faḍlān the most honest of authors writing in the classical Arabic tradition. His humanity and honesty keeps this text fresh and alive for each new generation of readers fortunate enough to share in its treasures."

39. For Krachkovskiľ”s translation of four "linking passages" (LP1-4), see Krachkovskiǔ, Puteshestvie, 26-29. See also Kovalevskiǐ, Kniga, 47-48.

40. Kovalevskiǐ, Kniga, 47.

41. Minorsky points out that the second Risāla cannot have been written before the year 348/959: see Minorsky, Travels in Iran, 5. 
Kovalevskil suggests they were members of the Bal'ami family-were engaged in making a fair copy of Ibn al-Faqīh's geography (for reasons unexplained), and they decided to append to it the Risālas and the Kitāb. They had the full text of the Risālas copied into the miscellany but created an abbreviated version of Ibn Faḍlān's text, considering the Kitāb overlong since, in their opinion, it contained information that would have been of little interest to Bukharan readers.

In proposing this conjectural and rather tenuous reconstruction of the genesis of the miscellany, Kovalevskil managed to account for the work's eastern provenance and for the widespread view, which he shared, that there existed a longer original version of Ibn Faḍlān's text of which the miscellany's version was an abridgment. ${ }^{42}$ However, his explanation took little note of the contents of the linking passages and did not tackle the question of why the editors compiled these texts in a single volume.

Further thoughts on the question of the patrons' identity and the process of the compilation of the miscellany were offered by Minorsky and Miquel. ${ }^{43}$ Minorsky rejected Kovalevskiî's proposal that Abū Dulaf's patron was al-Șāhị b. 'Abbād but concluded that he wrote the text in either Iran or Mesopotamia. Minorsky was also interested in the critical comments inserted in the Risālas by the editors but did not speculate on the editors' reasons for retaining their criticisms in the miscellany beyond stating that they obviously considered Abū Dulaf an unreliable source. Miquel accounted for the bizarre mixture of fiction and fantasy in the first Risāla with the suggestion that the patrons must have commissioned Abū Dulaf to write the two texts. He argued that Abū Dulaf's first Risāla was a response to their request for a picaresque account that combined observed facts and adab-like flourishes, while the second was closer to Abū Dulaf's preferred style of writing and reflected his interest in mineralogy, botany, and architecture. Miquel's theory addressed the particular styles of Abū Dulaf's writing but did not comment on the editorial linking passages. It is to these linking passages that we now turn. The following table lists the five passages along with the four main texts, their authors, and their place in Sezgin's facsimile of the Mashhad manuscript, and provides brief comments on their contents (see the next page).

42. Kovalevskiǐ, Kniga, 41-49.

43. Minorsky, Travels in Iran, 23-26; Miquel, Géographie humaine, 139-41. 
Table 2: Linking passages and texts in the miscellany.

\begin{tabular}{|c|c|c|c|}
\hline $\begin{array}{l}\text { Linking Passage (LP1-5) } \\
\text { or Main Text (T1-4) }\end{array}$ & Author(s) & $\begin{array}{l}\text { Page No. in } \\
\text { Sezgin's Facsimile }\end{array}$ & Comment \\
\hline LP1 & $\begin{array}{l}\text { The editors of the } \\
\text { miscellany }\end{array}$ & $\begin{array}{l}\text { Missing (see } \\
\text { Figure } 1 \text { below } \\
\text { for an image of } \\
\text { the first folio } \\
\text { of the Mashhad } \\
\text { manuscript } \\
\text { on which LP1 } \\
\text { appears) }\end{array}$ & $\begin{array}{l}\text { LP1 serves as a combined table of } \\
\text { contents and foreword. It begins with } \\
\text { a description of the contents of T1, } \\
\text { followed by brief summaries of T2-T4. }\end{array}$ \\
\hline $\mathrm{T} 1$ & $\begin{array}{l}\text { Ibn al-Faqīh al- } \\
\text { Hamadhānī }\end{array}$ & $2-347$ & $\begin{array}{l}\text { The text is an extended version of } \\
\text { those chapters of the geography that } \\
\text { deal with Iraq, Iran, and the Mashriq. }\end{array}$ \\
\hline LP2 & $\begin{array}{l}\text { The editors of the } \\
\text { miscellany }\end{array}$ & 347 & $\begin{array}{l}\text { Brief descriptions of } \mathrm{T} 2-\mathrm{T} 4 \text { (similar to } \\
\text { LP1) }\end{array}$ \\
\hline LP3 & Abū Dulaf & 347 & $\begin{array}{l}\text { Dedication preceding the first Risāla, } \\
\text { written by Abū Dulaf and reproduced } \\
\text { by the editors of the miscellany. }\end{array}$ \\
\hline $\mathrm{T} 2$ & Abū Dulaf & $347-62$ & $\begin{array}{l}\text { Abū Dulaf's first Risāla, a record of } \\
\text { his journey to the court of the king of } \\
\text { China and his return to Bukhara via } \\
\text { India. }\end{array}$ \\
\hline LP4 & Abū Dulaf & 362 & $\begin{array}{l}\text { Dedication preceding the second } \\
\text { Risāla, written by Abū Dulaf and } \\
\text { reproduced by the editors of the } \\
\text { miscellany. }\end{array}$ \\
\hline T3 & Abū Dulaf & $362-90$ & $\begin{array}{l}\text { Abū Dulaf's second Risāla, a } \\
\text { description of his travels in the } \\
\text { Caucasus and Iran. }\end{array}$ \\
\hline LP5 & $\begin{array}{l}\text { The editors of the } \\
\text { miscellany }\end{array}$ & $390-91$ & $\begin{array}{l}\text { Brief introduction to Ibn Faḍlān's } \\
\text { Kitāa }\end{array}$ \\
\hline $\mathrm{T} 4$ & Ibn Faḍlān & $391-420$ & $\begin{array}{l}\text { Description of Ibn Faḍlān's journey } \\
\text { from Baghdad to Bulghār }\end{array}$ \\
\hline
\end{tabular}

The linking passages read as follows:

LP1 (see Fig. 1): The book begins with bism Allāh rabb al-càlaminn wa-șallā Allāh 'alā nabīhi wa-ālihi ajma īn al-țāhirīn hādhā baqiyyat al-qawl 'alā al-Irāq wa-l-Bașra. The editors then list the section headings of Ibn al-Faqiih's book as follows: Iraq and Basra, Ubulla, al-Bațā̄ị, Wāsiț, Nabaț, al-Khūz, Baghdad, kuwar Dijla, Samarra (Surra man rā̄a), the raising of kharāj, al-Ahwāz, Fāris and its towns, al-Jabal, Qirmīsīn, Shabdīz, Hamadhān and Nihāwand, Ișfahān, Qumm, Rayy, Dunbāvand, Baywarāsaf, Qazwīn, 
Abhar, Zinjān, Tabaristan, and Khurasan and its towns and stories (akhbār). The final section is on the Turks and their akhbār, tribes, and customs (sharāij i ihim). ${ }^{44}$ Thereafter the text continues:

We say: I have added to what Aḥmad b. Muḥammad al-Hamadhānī [Ibn al-Faqīh] has written (ựīfu ilā mā șannafahu) at the end of his book (fi ākhir kitābihi), two letters/

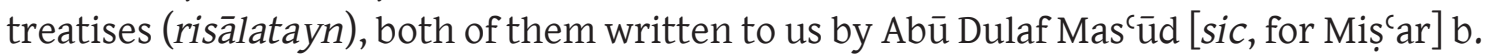
al-Muhalhil. In one of them he mentions reports about the Turks and China based on his experience of them (bi-mushāhadatihi dhālika). The other [Risāla] includes things that he saw with his own eyes and witnessed (ra'āhā wa-shāhadahā) in a number of countries. To that [Abū Dulaf's Risālas] we have added a book written by Aḥmad b. Faḍlān b. Rāshid b. Hamad [sic], client of Muhammad b. Sulaymān al-Hāshimī, [containing] reports about the Turks, the Khazars, the Rus', the Șaqāliba, and the Bāshghirds, drawing on what he came across and looked at [with his own eyes] (mimma waqafa 'alayhi wa-nazara ilayhi). For al-Muqtadir bi-1lāh sent him to the land of the Șaqāliba in 309[/921] at the request of their king, [who made this request] because he had a desire for Islam. [In his book] he related everything that he witnessed in these lands (mā shāhada fi[?] hādhihi al-buldān) and that which was reported to him (wa-mā [?] nuqila ilayhi). ${ }^{45}$

LP2:

We will mention [reading dhakarnā naḥnu for dhakara naḥnu in the text] in this place/ these places [i.e., in what follows] certain reports on countries that have never been mentioned before (dhakarnā naḥnu fị hādhā al-mawāḍi ashyā’ min akhbār al-buldān lam yudhkar). Among them are two Risālas written to/for us (katabahumā ilaynā) by Abū Dulaf Miș ${ }^{\top} a r$ b. al-Muhalhil al-Banāza'ì [sic, for Yanbū' ${ }^{c} \overline{1}$. In one of them he relates the stories ( $a k h b \bar{a} r$ ) of the Turks and India and other countries from his own experience of [them] (bi-mushāhadatihi dhālika). In the other [he writes about] things that he has seen and witnessed (ra'āhā wa-shāhadahā) in a number of countries (buldān). They deserve to be set down in this book, for they are of this kind [of writing] (min fannihi). Also of this kind [of writing] is a book put together by Aḥmad b. Faḍlān b. al-'Abbās b. Rāshid b. Hammād, mawlā of Muḥammad b. Sulaymān al-Hāshimī, concerning the akhbār of the Turks, the Khazars, the Rus', the Șaqāliba, and the Bāshghirds and others that he came across and looked at [with his own eyes] (mimmā waqafa calayhi wa-nazara ilayhi). Al-Muqtadir bi-1lāh sent him to the land of the Șaqāliba in 309[/921] at the invitation of their king, because he had a desire for Islam (bi-istid $\bar{a}$ malikihim dhālika raghbatan minhu fi al-islām). He related everything that he witnessed in these lands with his own eyes (jamī‘ mā shāhadahā fi hādhihi al-buldān bi-mu’āyanatihi wa-nazarihi).

44. These section headings differ a little from those in the text itself, giving slightly more detail in several cases while omitting one or two headings that occur in the text (such as the sections titled "The sawād of Iraq" and "Buildings and their special characteristics and marvels": see Ibn al-Faqīh, Buldān, 377 and 430).

45. The final sentence is obscure in the Mashhad manuscript. The translation is based on Kahle's and Krachkovskiǐ's reconstructions: P. Kahle, "Islamische Quellen zum chinesischen Porzellan," Zeitschrift der Deutschen Morgenländischen Gesellschaft, n.s., 13 [88] (1934): 1-45; Krachkovskiǐ, Puteshestvie, 28. 
LP3:

The first Risāla: Abū Dulaf Mas'̄̄̄d [sic] b. al-Muhalhil al-Banāza'ī [sic, for al-Yanbū̄ī̄] wrote [this] for/to us, telling us what he had witnessed and seen (dhikr mā shāhadahu wa-ra'âhu) in the lands of the Turks and India and China. He said: "When I saw you both, my lords (to whom I am but a slave, may God lengthen your days), craving writing and addicted to composition (lahijayni bi-1-ta'lïf mūla'ayni bi-1-tașniff), I did not wish to deprive your store of wisdom of anything that I had personally witnessed (waqa'at ilayya mushāhadatuhu [text has mushāhadatuhumā]) or any wonder that fate had thrown across my path...

\section{LP4:}

The second Risāla, which he [Abū Dulaf] sent to us after the one that we have transcribed (katabnāhā) ${ }^{46}-$ Abū Dulaf writes: "Praise be to God ... I prepared for you both ... a summary of my journey, which was from Bukhara to China ... and from there to India. ... In that account I mentioned some of the wonders of the countries I entered and the tribes I passed by. I did not make my account long for fear of prolixity. Now I see fit to prepare a shortened version (tajrīd) of a worthy epistle encompassing the greater part of what I witnessed ('āmmat mā shāhadtuhu) and encompassing most of what I personally observed (akthar mā 'àyantuhu), so that the perspicacious might benefit from it."

\section{LP5:}

This is the written account of Aḥmad b. Fạ̣lān b. al-`Abbās b. Rāshid b. Ḥammād, the envoy (rasūl) of al-Muqtadir to the king of the Șaqāliba. His patron was Muhammad b. Sulaymān. In it he records what he witnessed (mā shāhada) in the lands of the Turks, the Khazars, the Rus', the Șaqāliba, the Bāshghirds, and other peoples. It includes reports of their customs, stories about their kings, and many other matters pertaining to them.

\section{What Do the Linking Passages Tell Us about the Editors' Agenda-and Their Identity?}

The first four linking passages are written in the first-person voice, while the fifth is related by an anonymous narrator. LP5 refers to Ibn Faḍlān in the third person and alludes to the common theme of "eyewitness observation" that is also found in its predecessors. It is reasonable, therefore, to conclude that since it cannot have formed part of the Kitāb, it was most likely written by the editors as well. The linking passages convey two important messages to the reader: first, that all four texts are of the same kind or genre and belong together in the book for this reason; and second, that Abū Dulaf and Ibn Faḍlān's texts are both eyewitness reports-in other words, records of direct observations that the authors personally saw and put down in writing.

The claim that the four texts belong together because they all represent the same kind of writing appears in two consecutive statements in LP2. The first refers to Abū Dulaf's Risālas,

46. The primary meaning of the verb kataba is, of course, to write rather than to transcribe. See Section 6 for a discussion regarding the meaning of the word in this context. 
stating: "They deserve to be set down in this book, for they are of the kind [of writing that is in this book]' (inna ḥaqqahā an ... narsuma[hā] fi hādhā al-kitāb idh kānat min fannihi). What did the editors mean by this assertion? They claimed that both Abū Dulaf and Ibn Faḍlān were unknown authors who provided new information (ashyā’ min akhbār al-buldān lam yudhkar). The link they make with Ibn al-Faqìh's book appears to lie in the title that they give to the latter, Kitāb Akhbār al-buldān. Their claim amounts to the assertion that all three authors convey information about different regions of the world. The editors do not discuss the fact that each of these three shorter texts differs from Ibn al-Faqin's book in many respects; organization, content and voice (first- versus third-person) being among the most important, let alone the dissimilarity between the geographical work of an erudite writer and the narratives of two travelers.

The editors also underline the fact that the three new texts are all "eyewitness testimonies" of events, phenomena, and peoples that the authors observed directly in the course of their journeys. The key term used to convey the idea of witnessing, in the sense of the author's being present in person when the described event occurred, is mushähada. This is a word that is used in Islamic law to refer to the testimony that a court witness provides to the judge. It appears in all five linking passages, often in combination with a verb referring to the act of seeing or looking at what transpired (ra'ā, nazara ilā). The point that is emphasized by the consistent use of mushāhada/shāhada is that the authors convey what they actually experienced, thus explicitly ruling out the possibility that they invented what they describe. The assertion of this common characteristic of the three texts implies parity between Abū Dulaf's and Ibn Faḍlān's writings. In Ibn Faḍlān's case, the claim that his text was the fruit of eyewitness observation appears justified, given the accuracy and emotional transparency of his narrative. Although they stress the role of direct observation, the editors also acknowledge at one point that Ibn Fac̣lān included information that had been related to him by other parties (see mā nuqila ilayhi, the final phrase in LP1). Ibn Faḍlān himself frequently notes information that he heard from his Bulghār hosts and his translators, such as the remarks made to him by the ghulām Takin, who accompanied the mission. ${ }^{47}$

In Abū Dulaf's case, by contrast, the claim to eyewitness observation lacks credibility. Granted, he claims that he has tried to be concise when writing both Risālas in order to avoid prolixity; ${ }^{48}$ and the abbreviation of the texts, it might be surmised, could have resulted in the attenuation of the autobiographical voice. Furthermore, much of the botanical, mineralogical, architectural, and historical information he supplies, especially in the second Risāla, has the ring of truth and might have been the fruit of his personal knowledge, garnered from the many journeys he took across Iran. But his narrative has none of the immediacy of Ibn Faḍlān's Kitāb, since the author's voice is only rarely heard in the first person and, moreover, he often appears to be writing with his tongue firmly in

47. For example, Takīn informed Ibn Faḍlān about the giant who lived in Bulghār; see Montgomery, "Mission to the Volga," 232-33).

48. See LP4: "I did not make my account [in the first Risāla] long for fear of prolixity. Now I see fit to prepare a shortened version (tajrīd) [of the second Risāla]." 
his cheek, particularly when discussing the Turkish pastoralists whom he encountered at the beginning of the first Risāla (see Section 6). The second Risāla depicts a journey without a stated purpose; the reader is not informed why the narrator chose the routes that he did, whether he completed the lengthy course in one attempt, or whether his account is a composite of many individual expeditions. In addition, the itineraries followed in both Risālas, especially the first, are wayward and prolonged. Finally, Abū Dulaf's own claim, in linking passages 3 and 4, that he wrote down what he personally observed on his travels is contradicted by the editors' criticisms of his text.

The question is why both Abū Dulaf and the editors were so insistent on the claim of eyewitness testimony in respect of two texts in which it appears to be lacking. While the indulgent reader may chalk Abū Dulaf's own claims of mushāhada up to authorial vanity and a desire to be seen for the kind of writer that he clearly was not, the editors' approbation is more difficult to account for. They did, after all, insert critical comments at points where they judged the author to have exaggerated or made things up. The explanation may be that the editors were determined to boost their protégé's credibility and to raise his work to parity with Ibn Faḍlān's more persuasive narrative by claiming that both works were "of the same kind."

Could the editors' decision to append the three unknown texts to Ibn al-Faqin's wellknown book have been simply an imaginative way of bringing the three texts to a wider reading public? Perhaps the editors were really bona fide lovers of good literature (as Abu Dulaf claims they were in LP4) who wished to publicize newly discovered talent. Were their criticisms of Abū Dulaf's Risālas intended as lighthearted rebukes for minor infractions of the high standards of truthfulness that they expected of him? Did they believe, in spite of their criticisms, that Abū Dulaf was a genuine traveler who had accompanied the embassy and recorded all that he saw en route, only to stray into occasional hyperbole when writing up his adventures? If so, one might see the relative infrequency of their criticisms as a tacit acknowledgment of the truthfulness and accuracy of all the passages that they let pass without comment, including Abū Dulaf's descriptions of the Central Asian Turkish tribes at the beginning of the Risāla.

An open-minded reading that gives the benefit of the doubt to the editors' sincerity cannot be dismissed out of hand. But it severely strains the reader's credulity. Alternatively, should we assume that they were willing accomplices in Abū Dulaf's hoax, notwithstanding their demonstration of critical rigor? Did they deliberately aid and abet their protégé by identifying just a few minor lapses so as to reassure the reader that the remainder of his text had passed their scrutiny?

If they were indeed figures of literary repute, it is unlikely that they would have connived in this way. The members of the elite to which they allegedly belonged were generally happy to indulge the subversion of norms by their nudamä' because they enjoyed the entertainment, but they were less likely to have taken a leading role in a literary scam on a nadim's behalf, which might carry reputational risk. All the more so if, as Kovalevskii suggests, they had not been in touch with their protégé for several years and were no longer part of his immediate cultural milieu. Even if Abū Dulaf did not present the Risālas in the first instance to the Șāhib, as Kovalevskiǐ suggests, but rather to his two Bukharan 
patrons, the point about patronal constraint retains its force. The diversions of the majalis of eminent men were considered to be private business, enjoyed for the purposes of relaxation among a restricted circle of boon companions. Privileged patrons paid others to fool around and titillate them, but as a rule it was the nudamā' who cooked up elaborate hoaxes and told off-color jokes to amuse the patron, not vice versa.

If there was only a single mind behind this elaborate literary construction-the muted stropping of Occam's Razor being distinctly audible by this stage of our investigation-the finger of suspicion must fall on the person who stood to gain from its success: Abu Dulaf himself. Could it have been Abū Dulaf who compiled the miscellany and invented the fictive personae of the editors/patrons to boost the reputation of his own texts? His attempt to pass off both the parodic first Risāla and the rather more pedestrian second Risāla as shining examples of eyewitness reportage constituted a dual assault on the notion of mushāhada that was promoted by the linking passages. Given the difficulties of persuading others of the truth of individually observed experiences in far-off corners of the world, such playful nonsense may well have amused the real dedicatee of the miscellany (who could have been the Șāhib or someone of similar stature). ${ }^{49}$

Yet if Abū Dulaf's goal was to promote his own work, why did he go to the trouble of copying out an extended version of Ibn Faqin's book, or at least half of it, as the foil for his hoax? Perhaps the miscellany's version of the Buldān was a gift he offered his patron in expectation of a reward. Since there was probably more than one version of Ibn al-Faqih's book in circulation in the years after its composition, the presentation of a rare edition of it to a bibliophile would be regarded as a valuable gift. ${ }^{50} \mathrm{~A}$ well-connected poet like Abū Dulaf, who was a friend of the great bibliographer Ibn al-Nadim ${ }^{51}$ and probably had a large network of bookish contacts stretching from Baghdad to Bukhara, must have known where the rare copies of famous books were to be found.

But there is a more significant reason why Abū Dulaf may have selected this particular version of the Buldān as the principal text of the miscellany. For at the end of the Buldān, there is an anomalous section on the towns of the Turks, which seems quite out of place. It has none of the refinement of Ibn al-Faqin's style and its tone is sombre and harsh: the author describes the Turks as barbarians who lack all the graces of civilized nations and spend their lives in conflict with one another. The remarkable feature of this section is that although it stands out from the rest of the book to which it belongs, it bears a strong

49. See Montgomery, "Travelling Autopsies," 19: "In a society in which authority is generated through, and embodied in, textual sources (or oral versions with comparable status), the problem for the traveller or the empirical scientist is the endowment of experience and experiment with appropriate authority."

50. For recent suggestions that well-known books, such as Ibn Khurradādhbih's Masālik, probably existed in multiple versions during the lifetimes of their authors, see the following: J. E. Montgomery, "Serendipity, Resistance and Multivalency: Ibn Khurradādhbih's Kitāb al-Masālik wa-l-Mamālik," in On Fiction and Adab in Medieval Arabic Literature, ed. P. F. Kennedy (Wiesbaden: Harrassowitz, 2005), 177-230; T. Zadeh, Mapping Frontiers across Medieval Islam: Geography, Translation and the 'Abbasid Empire (London: I. B. Tauris, 2017); T. Zadeh, "Of Mummies, Poets and Water Nymphs: Tracing the Codicological Limits of Ibn Khurradādhbih's Geography," in 'Abbāsid Studies 4, ed. M. Bernards, 8-75 (Warminster: Gibb Memorial Trust, 2013).

51. See B. Dodge, trans., The Fihrist of al-Nadim: A Tenth-Century Survey of Muslim Culture 2 (New York: Columbia University Press, 1970), 829-30, for Abū Dulaf's acquaintance with Ibn al-Nadīm. 
stylistic resemblance to the first part of Abū Dulaf's first Risāla, which follows directly after the Buldān in the miscellany. The link between the last pages of Ibn al-Faqīh's Buldān and the first Risāla appears to have been deliberately signalled in the first of the editorial "linking passages". ${ }^{52}$ As already noted, is also precisely at the juncture between these two texts that LP2 includes the enigmatic statement, 'They [i.e., the Risālas] deserve to be set down in this book, for they are of this kind [of writing] (see Section 4). It seems that here, in the resemblance between these two adjacent texts, we may have an explanation for the oblique claim made by the "editors." We turn now to a detailed analysis of the issue.

\section{The Section on the Turkish Towns in the Buldān and the First Part of Abū Dulaf's First Risāla}

The remarkable but hitherto little studied section of the Buldān in question is entitled "Some of the towns of the Turks and their marvels" (Dhikr ba'd mudun al-atrāk

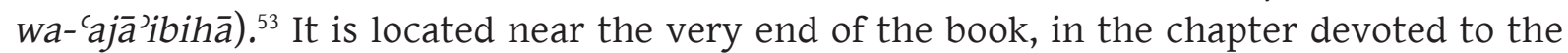
Turks. ${ }^{54}$ I will briefly summarize the chapter in which it appears before highlighting the anomalous characteristics that distinguish the section on the Turkish towns. I will then compare this section on the settled Turks in the Buldān with Abū Dulaf's description of the pastoralist Turks among whom he traveled on his journey to the court of the "king of china."

The chapter on the Turks opens in a manner typical of Ibn al-Faqīh with several hadiths, related by the Prophet and his Companions. These include warnings of the Turks' predicted domination of the world at the end of times. The introduction is followed by a list of Turkish tribes, which includes the Qarluq (Kharlukh), the Badhakshiyya, the Ghuzz, the Toghuzghuz, the Kimak (Kìmāk), the Pechenegs (Bāshnākiyya), and the Shariyya. Of these, the Badhakshiyya is not found in any other sources on the Turks. ${ }^{55}$ After the list, the author provides a series of short notes and brief anecdotes in the witty, elegant style of the rest of the Buldān. They include a summary of an encounter between an Umayyad envoy and the Turkish king whom the envoy had been sent to convert as well as short notes on an impregnable Turkish town, the fecundity of Turkish ewes, a Turkish ritual for the swearing of oaths, Turkish family culture, and the availability of khutu (variously translated as the horn of the rhinoceros, the walrus, or the narwhal) in their lands. These brief and randomly sequenced notices are standard fare for Ibn al-Faqīh. They are followed by two

52. The relevant phrase in LP1 is uḍifu ilā mā șannafahu fi ākhir kitābihi risālatayn ("I have added two risālas to that which he (Ibn al-Faqih) composed at the end of his book"). The allusion to the end of Ibn al-Faqīh's book is surely a reference to the passage on the Turkish towns, which forms the last section of the Buldān. The editor is here, exceptionally, speaking in the first-person singular.

53. See Ibn al-Faqīh, Buldān, 643-48, and 34-37 for al-Hādī's commentary on the section.

54. For the chapter on the Turks (Al-qawl fi al-Turk) see Ibn al-Faqīh, Buldān, 633-49. The Mukhtașar has a much-abbreviated version of this chapter that occurs, without a specific heading, in the final couple of pages in the chapter on Khurasan (Al-qawl fi Khurāsān); Ibn al-Faqīh, Mukhtașar, 314-30.

55. The "Badhakshiyya" may be a corruption of al-Adhkahiyya, the Ädhgish or Ägdhish/Igdish, noted in several accounts and commented on by Kāshgharī (Professor Peter Golden, personal communication, February 2019). 
longer passages, the first a description of Tamim b. Bahr al-muttawwi $\xi_{1}$ 's journey to the Uighur capital ${ }^{56}$ and the second a secretary's report on the Samanid ruler Ismā'îl b. Ahmad's (d. 295/907) terrifying encounter with Turkish shamans who used a "rainstone" to summon up a storm that threatened to overwhelm his army. The section on the Turkish towns appears next, and it is in turn followed by the final pages of the book, which contain a list of the titles of the Turkish rulers and their neighbors. ${ }^{57}$

The original source of much of the information in Ibn al-Faqin's chapter on the Turks was Ibn Khurradādhbih's al-Masālik wa-1-mamālik. ${ }^{58}$ However, the section on the Turkish towns does not occur in any of the known manuscripts of Ibn al-Khurradādhbih's book. Ibn al-Faqih reports it on the authority of one $\mathrm{Sa}{ }^{\mathrm{C}} \overline{\mathrm{i}} \mathrm{d} \mathrm{b}$. al-Hasan al-Samarqandī. ${ }^{59}$ How his account came to be included in the miscellany's version of the Buldān is not known, although it is likely that it came from an eastern source. ${ }^{60}$ The section stands out for the contrast it provides with the rest of Ibn al-Faqiih's geography. It is syntactically uncomplex, crude, and direct, and it lacks any hadith or Qur'an references. In contrast to the whimsical style that characterizes much of the rest of the Buldān, in this section satire and caricature come to the fore. Short sentences and simple grammatical structures are used to describe the Turkish population as irredeemably barbaric and uncultured. Incest, adultery, public sex, a lust for fighting, religious deviancy, and improper treatment of the dead are among the main themes. Lurking behind these lurid tales is the recurrent impression that the author is not reporting factual data on the Turkish town-dwellers but indulging in a measure of black humor: his pointed remarks and glib juxtapositions discourage the reader from taking his report at face value. The description of the second named town in the list serves as a representative example:

Another of their towns is called H.y.W.S. It is a large town close to al-Shash. ${ }^{61}$ Its people follow no religion and are the worst of God's creatures. They conduct raids upon each other, and the stronger kill the weak. A brother is not safe from his brother nor a father from his sons. They eat all kinds of animals. Illicit sexual intercourse is widespread among them. A man might enter the dwelling of another and bed his wife while the

56. See V. Minorsky, “Tamìm b. Bahr's Journey to the Uyghurs," Bulletin of the School of Oriental and African Studies 12, no. 2 (1948): 275-305.

57. Brief references to some of this material on the Turks, including the rainstone and the list of titles, appear in the chapter on Khurasan in the abridged version of Ibn al-Faqīh's book (Ibn al-Faqīh, Mukhtașar, 329).

58. See Ibn Khurradādhbih, al-Masālik, 31 and 39-40.

59. Ibn al-Faqīh, Buldān, 643.

60. See Zadeh, "Of Mummies," 51, who notes that Ibn al-Nadīm's Fihrist states that Ibn al-Faqīh "ripped off” (salakha) al-Jayhānī’s geography; see Ibn al-Nadīm, Fihrist, ed. Ayman Fu’ād Sayyid, (London: Mu’assasat al-Furqān li-1-Turāth al-Islāmī, 2009), 1:473-74 (= ed. Dodge, 1:337). Could it be that the section on the Turkish towns under discussion here was originally in al-Jayhānī’s Masālik? Perhaps Sa`īd b. al-Hasan was one of al-Jayhānì's informants on the world of the Turks. See Gardīzī's Zayn al-akhbār, translated into English by C. E. Bosworth, as The Ornament of Histories: A History of the Eastern Islamic Lands AD 650-1041; The Persian Text of Abū Sa'īd 'Abd al-Hayy Gardīzī (London: I. B. Tauris, 2018), 57, for the remark that al-Jayhānī got his information from a network of informants who had knowledge of the Eurasian steppelands.

61. Al-Shash is located on the site of modern-day Tashkent. 
householder looks on, neither expressing anger nor censuring what he sees. They are not courageous, but they are good-looking: most of their men are effeminate and drink blood. In the middle of their town is a large lake; when one of them dies, he is thrown in the lake. ${ }^{62}$

Of the remaining nine towns (named D.y, S.W.r, J.r.y.s.m [= Jarīsam, Juraysim?], Aghras, Karshīm, D.k.S, Kīsāh, Dānī, and S.K.W.b), seven are described in similarly negative terms. Aghras and D.K.s are treated more favorably, although the religious gullibility of the people of Aghras is described in comic fashion. They are said to have claimed that they worshipped their idols because the latter were sinless and able to intercede on their behalf with their god, and that that their huge idol temple descended, fully formed, straight out of the sky into their town. In general, however, the text portrays the Turks as the sort of mysterious and grotesque figures one might expect to find at the ends of the earth, something like the creatures who lived on the other side of Alexander's wall, which divided the barbarian from the inhabited world. ${ }^{63}$

The ironic tone, the short sentences (perhaps intended to sound like notes written by a weary traveler on the road), and the simple syntax are features of this section. None of the towns bears a name that can be related to any known settlement in the region. ${ }^{64}$ As we have noted, the section is remarkable not only for the contrast it forms with the rest of the Buldān but also for the similarities it displays with the first part of Abū Dulaf's Risāla, which follows it. The final pages of the Buldān satirize the settled Turks, just as Abū Dulaf mocks the Turkish tribes among whom he traveled. Yet whereas the Turkish towns in the Buldān are described in dark tones, Abū Dulaf inclines toward lighthearted absurdity. In one case, two passages dealing with near-homonymous names (Baghrāj in the Risāla and Aghras in the Buldān) appear to mirror each other to some degree. The passage on the Baghrāj deserves to be quoted in full:

Then we left [the Jikil] and entered [the territory of] the tribe known as the Baghrāj. They have whiskers but no beards. They make good use of their weapons, both as mounted warriors and as foot soldiers. They have a great ruler (malik), of whom is it said that he is an 'Alid. [It is said that he is] a descendant of Yahyā b. Zayd ${ }^{65}$ and that he has a golden book on the back of which are poetic verses that elegize Zayd. They worship this book. For them, Zayd is the king (malik) of the Arabs and 'Alī b. Abì Țâlib, may God be pleased with him, is the god (ilahh) of the Arabs. They appoint their rulers only from among the progeny of this 'Alid. When they turn their faces to the sky, they

62. Ibn al-Faqīh, Buldān, 643-44.

63. See al-Tabarī's description of the three types of creature among the people of Gog and Magog in his tafsīr: E. von Donzel and C. Ott, "Yādjūdj wa-mādjūdj," in Encyclopaedia of Islam, 2nd ed. (Leiden: Brill Online, 2012).

64. Al-Hādī identifies the town of S.K.W.b as Pskov in western Russia, but the attribution is not persuasive; see Ibn al-Faqīh, Buldān, 34-37.

65. A descendant of the Prophet and the progenitor of the Zaydī Shī'ī sect, Yahyā was a rebel whose fame endured in the Mashriq; see W. Madelung, "Yahyā b. Zayd," Encyclopaedia of Islam, 2nd ed. (Leiden: Brill Online, 2012). 
open their mouths and gaze upward and say: "The god of the Arabs descends from [the sky] and ascends [to it]." The marvel of the progeny of Zayd whom they make their kings is that they have beards, huge noses, and enormous eyes. Their food is millet and the meat of the ram. There is neither a cow nor a goat in their land. They wear only felts. We traveled among them for a month in fear and dread, and gave them a tenth of everything we had with us... ${ }^{66}$

Abū Dulaf notes that the Baghrāj, whose kings were all of 'Alid descent, considered 'Alī $b$. Abì Țâlib the god of the Arabs. They believed, moreover, that the "marvel" ('ajība) of their kings lay in the fact that the kings were bearded, whereas his subjects had only whiskers, without beards. Like the people of Aghras in the Buldān, they claimed direct communication between heaven and earth. Whereas the people of Aghras believed that their idol temple descended from heaven, the Baghrāj had the habit of staring up at the sky, open-mouthed, for they held that 'Ali descended from the heavens and returned there.

In addition to this direct parallel, there is a pool of common terms and descriptions used for the Turks in both works: some are described as savages (hamaj) ${ }^{67}$ others conduct raids upon their neighbours; ${ }^{68}$ some drink wine; and several follow deviant sexual practices. ${ }^{69}$ When read in sequence, the two passages create a bridge, a transitional zone, in which the reader is taken from the discussion of the settled Turks to the pastoralist Turks, so that the Risāla forms a complement to the Buldān, providing contextual as well as tonal continuity. Were it not for the parodic elements in both texts and correspondences such as those between the passages on the Aghras and the Baghrāj, one might still be inclined to give Abū Dulaf the benefit of the doubt and accept that the record of his experiences in the steppe happened to complement Sa'īd b. al-Hasan's observations on the Turkish towns so neatly that he was inspired to place his Risāla in the miscellany at this point. But neither text reads like an objective eyewitness report. Given the fact that the Risāla must have been written after the Buldān, the most plausible explanation is that Abū Dulaf constructed the first part of the Risāla in such a way as to allow him to make the claim, as the author of the first two linking passages, that his Risāla formed a worthy complement to the Buldān. The suggested linkage of the two texts may sound obscure and tenuous to a degree, but this was the kind of literary trickery that Abū Dulaf enjoyed-as we will see from a brief summary of his professional biography.

\section{The Professional Biography of Abū Dulaf al-Khazrajī}

The argument that Abū Dulaf compiled the miscellany as a literary hoax has thus far relied exclusively on textual analysis. But in addition to the evidence of the miscellany

\footnotetext{
66. Sezgin, Majmū'a, 349-50.

67. The inhabitants of J.r.y.s.m (Ibn al-Faqīh, Buldān, 645) and the Bajanāk (Yāqūt, Mu cjam 3:441) are described as hamaj (savages).

68. Mutual raiding (the same phrase is used in both sources - yughīru ba'duhum 'alā ba'din) was practised by the inhabitants of H.y.w.s. (Ibn al-Faqīh, Buldān, 643) and the Bajanāk (Yāqūt, Mu'jam 3: 441).

69. Sexual deviancy was ascribed to the inhabitants of H.y.W.s and D.k.s (among other towns) (Ibn al-Faqīh, Buldān, 644-645) and to the Jikil and Bajanāk tribes ((Yāqūt, Mưjam 3:441).
} 
itself, we are fortunate in knowing quite a bit about Abū Dulaf's professional biography as a poet, nadim, traveler, and trickster. From these glimpses into his activities at the courts of his real patrons, we are able to reconstruct the outlines of a career in which he sought monetary reward for public performances and other services that he provided for the wealthiest members of the political and scribal elite of Iran.

Abū Dulaf was a notorious itinerant entertainer, with a fondness for playing tricks on his audience and his patrons and a reputation for hyperbole and quackery. ${ }^{70} \mathrm{He}$ was what might be called a "professional scoundrel," who thrived by delighting, shocking, and exasperating his wealthy patrons with his wit and naughtiness. He moved from one majlis to another throughout his long life, bantering, pontificating, and scandalizing wherever he went, and died some time in the second half of the fourth/tenth century. ${ }^{71}$ All of his securely identifiable patrons were associated with various Buyid courts in Rayy, Ișfahān, and Shīrāz. They included the viziers Ibn al-'Amīd and al-Sāhib b. 'Abbād, as well as the great Buyid ruler 'Adud al-Dawla (d. 371/981). ${ }^{72}$ Although we have no direct evidence of his association with the Samanid and Saffarid elites, given his knowledge of the Samanid and Saffarid courts it is probable that he was also a popular figure in the salons of the Mashriq.

Abū Dulaf adopted the persona of a wandering poet, of no fixed abode. ${ }^{73}$ His peripatetic existence allowed him to traverse the social boundaries that divided the educated elites from the vast and growing urban "underworld" of the Islamic city. He claimed intimate knowledge of the so-called Banū Sāsān, the urban underclass vividly brought to life by Edmund Bosworth in his dazzling monograph on the "medieval Islamic underworld." 74 These men (and a few women) made their living by indulging in all sorts of deceitful and foul practices involving fraud, impersonation, and self-mutilation, by which means they exploited the good will and charitable inclinations of their fellow citizens. Abū Dulaf contributed to the well-established literary subgenre of sukhf (shameless scurrility), in which men of letters delighted in giving detailed descriptions of the horrifying lengths to which tricksters and scoundrels would go in order to make a living. Al-Jāhị (d. 255/868) devoted a part of his "Book of Misers" (Kitāb al-bukhalā') to the story of Khālid b. Yazīd, the leader of the beggars (mukaddūn) in Basra, in whose biography the perpetrators of various

70. See C. E. Bosworth, The Medieval Islamic Underworld: The Banū Sāsān in Arabic Society and Literature (Leiden: Brill, 1976), 1:58-60, for the dangerously inept medical advice he offered the vizier Ibn al-'Amīd and the vizier's dismissive rejection of his claim to descent from the famous physician Abū Bakr al-Rāzī.

71. See R. Bulliet, “Abū Dolaf al-Yanbū c̄ì,” in Encyclopaedia Iranica, online ed., updated 2011. He died in his late eighties, according to al-Tha'ālibī (see Bosworth, Islamic Underworld, 1:76).

72. See C. Cahen, "Ibn al-'Amīd," in Encyclopaedia of Islam, 2nd ed.; C. Cahen and C. Pellat, "Ibn 'Abbād," in Encyclopaedia of Islam, 2nd ed.; and especially M. Pomerantz, Licit Magic: The Life and Letters of al-Ṣāhib b. 'Abbād (d.385/995) (Leiden: Brill, 2018) for an excellent discussion of the literary accomplishments of al-Sāhib b. 'Abbād, which, however, says little about the latter's predilection for the kind of lighthearted banter in which Abū Dulaf specialized. For the reward given him by 'Adud al-Dawla for besting an opponent in a humorous exchange of invective, see below.

73. Ibn al-Nadīm calls him a "globe-trotter" (jawwāla), probably alluding to his tendency to move from one court to another (or perhaps in ironic reference to his frenetic itineraries in the first Risāla?); Minorsky, Travels in Iran, 6.

74. Bosworth, Islamic Underworld. 
kinds of hideous and unseemly acts of deception are described. Some years later, the qādi Abū al-'Anbas al-Șaymarī (d. 275/888), perhaps taking his cue from al-Jāḥiz, wrote several now lost treatises on behaviors regarded as aberrant, including pimping, prostitution, masturbation, and pederasty, that were listed by Ibn al-Nadim..$^{75}$ This zany literary output earned al-Șaymarī the posthumous honor of having a maqāma written in his name by Badīc al-Zamān al-Hamadhānīi. ${ }^{76}$

Abū Dulaf's contribution to the field was a long poem, the Qasīda sāsāniyya, which he wrote for al-Ṣāhib b. 'Abbād. In it he listed in gory detail the working practices of many different classes of scandalous charlatans, including, for good measure, the reigning caliph, al-Muțī li-1lāh (d. 363/974), whom he portrayed as an impoverished beggar searching for crumbs at the table of his Buyid masters. ${ }^{77}$ The poem celebrates the figure of the wandering "beggar lord," voiced in the first person by the poet, who takes on the task of introducing each of the poem's disreputable characters. The poet takes aim at the ostentatiously pious, targeting the claimants to membership of the Prophet's family and the long-bearded shaykh in the same breath as the self-mutilating beggar, so that both parties, the allegedly devout and the doggedly salacious, are brought down to the same level. ${ }^{78}$ The poem's exposure of licentious indulgence is often taken to an extreme. ${ }^{79}$ The Qasīda sāsāniyya is significant for our purposes by dint of its form as much as by its racy content, because Abū Dulaf inserted within the poem an interlinear gloss, which he used to amplify his scurrilous poem with asides detailing the Banū Sāsān's most repulsive practices and to supply explanations of the recherché terms used by them. ${ }^{80}$ Like al-Ṣaymarī, Abū Dulaf may have taken his cue from al-Jāhiz, for the "Book of Misers" also displays a keen interest in the explication of the rare and refined terminology used by the book's gallery of rogues. The glossary in Abū Dulaf's poem provides evidence of his taste for intertextual intervention that may be compared with the paratextual framework of the Mashhad miscellany. Both devices, that in the poem and that in the prose work, attest to Abū Dulaf's proclivity for multilayered textual productions, which is also evident in the interjections of his "patrons" in the Risālas and in the fluid notion of authorial personality that characterizes these works.

75. Bosworth, Islamic Underworld, 1:31.

76. Bosworth, Islamic Underworld, 1:31. For Abū Dulaf's posthumous association with the maqāma genre, see Bosworth, Islamic Underworld, 1:79, citing al-Tha'ālibī's Yatìmat al-dahr. Al-Tha'ālibī notes that Badī' al-Zamān put some of Abū Dulaf's poetry into the mouth of the protagonist of his maqāma, Abū al-Fath al-Iskandarī.

77. Bosworth, Islamic Underworld, 1:76.

78. See, for example, verses 52-53 in Bosworth, Islamic Underworld, 2:196-97: "And the one who lifts up his voice during the prayers in the mosque, in the mornings and in the afternoon. / And the one who feigns an internal discharge, or who showers the passers-by with his urine, or who farts in the mosque and makes a nuisance of himself, thus wheedling money out of people."

79. See, for example, verses 25-26 in Bosworth, Islamic Underworld, 2:192: "Our company includes every person avid for copulation, for vulvas and anuses indifferently. / And of our number is every person who masturbates, with a swollen penis, a formidable weapon."

80. See, for example, the gloss to verse 53 in Bosworth, Islamic Underworld, 2:197: "Dashshasha is when he inserts a porridge-like substance into his rectum, taking it as a clyster. He then goes to sleep by the roadside and the substance oozes out of his anus like the wheaten porridge dashīsha ..." 
Abū Dulaf was probably not the first writer in the classical period to have adopted a fictive identity in the person of the editors of the Risālas. Al-Jāhiz himself, whose literary skills Abū Dulaf admired and emulated, may have invented the figure of an anonymous critic whom he addresses at the beginning of the Kitāb al-Hayawān. ${ }^{81}$ He appears to have created this virtual critic as a foil to allow him to show off the merits of his earlier works and to preempt criticism of the Kitāb al-Hayawān. ${ }^{82}$ As for Abū Dulaf, it seems he may even have laid a couple of oblique clues to the true identity of the "editors" in the dedications that he wrote to his two patrons at the beginning of his Risālas. The evidence is tantalizingly thin but worth noting, given Abū Dulaf's demonstrated taste for literary horseplay. ${ }^{83}$

Abū Dulaf lived by his literary accomplishments and performances. ${ }^{84}$ Like many nudamā' who attended the courts of wealthy patrons, he declaimed and wrote prose and poetry in the expectation of financial reward. For an extempore performance in which he reeled off a long list of exotic luxuries from different regions of the world, he received a gift in coin and the sardonic title of shāhanshāh from none other than the great Buyid king 'Adud al-Dawla. ${ }^{85}$ He presented the Qașìda sāsāniyya to the Sāhib, accompanied by the explanatory gloss to help him understand the more recondite words and phrases employed and to squeeze every last drop of smut and scatological excess from the text, and he obtained a generous reward for his endeavor. ${ }^{86}$ It is quite possible that the miscellany was put together by Abu Dulaf for similar reasons-as an elaborate plaything designed to elicit a monetary reward. The miscellany, like the qașida, was a rich and complex offering. Ibn al-Faqīh's text, written over half a century earlier and admired throughout the Islamic world, appears in a version that is still today unique and may in Abū Dulaf's time have been a rarity. The three new texts represented a full spectrum of variants within the loose category of eyewitness reportage: from the subversive parody and patent artifice of the Risālas to the precise detail and personal drama of the Kitāb, they presented a pleasingly distorting series of perspectives on the fraught nature of the processes of direct eyewitness testimony (mushāhada), a theme

81. J. E. Montgomery, Al-Jāhiz: In Praise of Books (Edinburgh: Edinburgh University Press, 2013), 224-38. In his section on the "Enigma of the Addressee," Montgomery lists eight possible options in relation to the Kitāb al-Hayawān, of which the sixth is that "the address may be a rhetorical device, a fictive conceit."

82. G. Schoeler, The Genesis of Literature in Islam: From the Aural to the Read (Edinburgh: Edinburgh University Press, 2009), 101-2.

83. First, in LP3, Abū Dulaf praises his patrons, saying they were "craving writing and addicted to composition" (lahijayni bi-1-ta'lif mūla'ayni bi-1-tașnīf). Although the context demands that tașnïf be understood as the (result of) composition, i.e., written text(s), the word is normally used to refer to the process of writing a text, that is, the job of the author. Could it be that Abū Dulaf is using this ambiguity to hint at the patrons' composition of the Risāla? In the same vein, in LP4, it appears that the two "editors" make a covert admission to being the authors of the second Risāla. The admission hangs on the interpretation of the word katabnāhā ("we wrote it [the risāla]"), which an initial reading would suggest should be read as "we [physically] wrote it [out]," i.e., had it copied into the miscellany, but taken in a literal sense would mean "we authored it."

84. See al-Tha'ālibī’s comment that Abū Dulaf liked to keep "his knife well sharpened in begging for gifts"; Bosworth, Islamic Underworld, 1:76.

85. C. E. Bosworth, The "Lațāif al-Ma'ārif" of Tha'ālibì: The Book of Curious and Entertaining Information (Edinburgh: Edinburgh University Press, 1968), 145-46.

86. Bosworth, Islamic Underworld, 1:76, citing al-Tha‘ālibī’s Yatīmat al-dahr. 
insistently promoted by the book's "editors." The identification of the latter as Abu Dulaf himself is the puzzle at the core of book, a puzzle that was surely designed to be solved by an attentive reader. If and when the penny dropped, Abu Dulaf must have hoped that his patron would chuckle at his audacity and throw him a bag of coins.

\section{Further Thoughts}

Several questions remain to be addressed relating to Abū Dulaf's role as the editor of the miscellany. On the one hand, the above account has largely avoided examination of the intellectual and cultural background of the text, both the literary world at large and the majālis of his patrons, particularly al-Ṣāhib b. 'Abbād. The recent studies of James Montgomery and Travis Zadeh, in particular, raise important issues concerning the emergence of travel accounts in the third-fourth/ninth-tenth centuries that are pertinent to the study of the miscellany and to the literary status, production, and reception of the Kitāb. ${ }^{87}$

Recent readings of the Kitāb have been strongly influenced by the strident insistence of the editorial linking passages that the text was the fruit of the eyewitness observations of its author. However, if the linking passages were concocted by Abū Dulaf primarily for the purpose of boosting the credibility of his own texts, the reader should be careful to distinguish between what Ibn Faḍlān claimed to have written and what his editor said he had written. The reader is primed by the linking passages to think of Ibn Faḍlān as the paragon of truthful reporting, but although Ibn Faḍlān frequently makes reference to what he saw, he does not fetishize his role as an eyewitness observer as does The Faber Book of Reportage, which cites his description of the Rus' chief's funeral as an outstanding example of the medieval reporter's art. We should perhaps allow him his few exaggerations and inventions without trying too hard to excuse him for his perceived shortcomings as a reporter.$^{88}$ Since the work's discovery in the miscellany in the early twentieth century, it could be said that the Kitāb has been treated more like a modern text than a medieval text. For example, the comparative accounts to which Montgomery has referred in an effort to elucidate the mysteries of the Kitāb include several dating to the period of eighteenth- and nineteenth-century European colonialism, the circumstances of which were a far cry from the early Islamic exploration of the Eurasian steppelands. ${ }^{89}$ Both the Kitāb and the Risālas should, as far as possible, be restored to their original context by returning them to their

87. In addition to the works listed in the bibliography, see also J. E. Montgomery's "Ibn Faḍlān and the Rūsiyyah," Journal of Arabic and Islamic Studies 3 (2000): 1-25.

88. See Montgomery's perceptive comments on John Carey's definition of "good reportage" apropos of his inclusion of Ibn Faḍlān's description of the Rus' chief's funeral in The Faber Book of Reportage: J. E. Montgomery, "Pyrrhic Scepticism and the Conquest of Disorder: Prolegomenon to the Study of Ibn Fadlān," in Problems in Arabic Literature, ed. M. Maroth, 43-89 (Piliscsaba: Avicenna Institute of Middle Eastern Studies, 2004), 44-51.

89. For example, taking his cue from G. Obeyesekere's 1998 study of accounts of Fijian cannibalism, Montgomery suggests that the Bulghār and the Rus' may have exaggerated the terrors of the Northern lights and the funerary customs of the Rus', respectively, in an attempt to intimidate their Muslim visitors ("Pyrrhic Scepticism," 72-73). This interpretation could arguably be said to reflect a notion of bilateral colonial-era relations that had no parallel in fourth/tenth-century Eurasian steppelands. The topic merits further discussion. 
proper place as component elements of Abū Dulaf's majmū'a. It would also be worthwhile to reconsider the reception of all three texts by Yāqūt, the first author who cited them extensively, and to gauge how far his interpretation of both texts, as well as that of later writers, was affected by the editorial commentary..$^{90}$

A second set of questions relates to the nature and purpose of the mission to Bulghār, long considered an "Abbasid" embassy. Various unresolved anomalies in the story of the mission remain, principally its extraordinary failure to achieve its most important task-the delivery of the promised funds to the king of Bulghār. The case for seeing the mission not as an official caliphal enterprise but as a private project undertaken by a band of entrepreneurs who wished to use their status as caliphal envoys to challenge Samanid/Khwarazmian authority over the Bulghār was first laid out by the Khwārazmshāh when he met Ibn Faḍlān and his fellow emissaries in his capital city. ${ }^{91}$ The Khwarazmian ruler identified Takin the ghulām, Ibn Faḍlān's interpreter, as the main plotter. Indeed, Takīn's blithe confidence in recommending that the mission push on to Bulghār in spite of the lack of funds suggests that he was determined to complete the journey, come what may, because to abandon the mission would have fatally undermined his scheme. ${ }^{92}$ The idea deserves closer scrutiny than it has received until now. If there were any substance to it, one would have to ask what the extent of Ibn Faḍlān's involvement in the plot was. The answer to this question must surely be that even if he was not complicit, he probably knew about it from the start and accepted his appointment to the embassy in the knowledge that he was joining a dubious enterprise. His compromised position most likely had a material effect on why, how, and where he produced the Kitāb, which in turn may have been a significant factor in its inclusion in the miscellany. ${ }^{93}$

Finally, much remains to be explored in relation to Abū Dulaf and his place in the classical Arabic literary canon. The Risālas merit closer attention than it has been possible to give them here. Furthermore, Abū Dulaf's role as a literary hoaxer of the first order gives pause to think again about Badī‘ al-Zamān al-Hamadhānī's remark that he put some of Abū Dulaf's material into the mouth of his own protagonists in one of his maqāmas. ${ }^{94}$ The proposition that he was the compiler and editor of the miscellany strengthens the case that he prefigured the heroes of the maqāma not only in his lifestyle but also in his literary production. Many of the elements for which the classical maqāma is well known are reflected in Abū Dulaf's editorial role, as well as his extant poetry and prose. The itinerant hero who is also a trickster, the penchant for picaresque humor, the fictionalization of reality, the episodicity

90. These themes will be pursued in W. L. Treadwell, "Ibn Faḍlān and the Mashhad Miscellany."

91. Montgomery, "Mission to the Volga," 194-97.

92. For Takīn's extraordinary indifference to the perceived danger of arriving penniless in Bulghār, see Montgomery, "Mission to the Volga," 198-99: "I [Ibn Fac̣lān] said to them [Takīn and Bārs] ...- 'You will be at the court of a non-Arab king, and he will demand that you pay this sum. 'Don't worry about it,' they replied, 'he will not ask us for them [the coins]. ' He will demand that you produce them. I know it,' I warned. But they paid no heed."

93. See W. L. Treadwell, "The "Abbasid' Mission to the Bulghār Court (309-310/921-922) Reconsidered," (forthcoming).

94. Bosworth, Islamic Underworld, 1:79. 
of the constituent stories that make up the whole: these are all present in Abū Dulaf's works as well. ${ }^{95}$ Fiction as a staple element of classical Arabic literature is said to have arrived only with the development of the early maqāma. Abū Dulaf seems to have played an important role in anticipating this process by embodying and elaborating the character of the roguish narrator before it secured universal recognition in the maqāma genre.

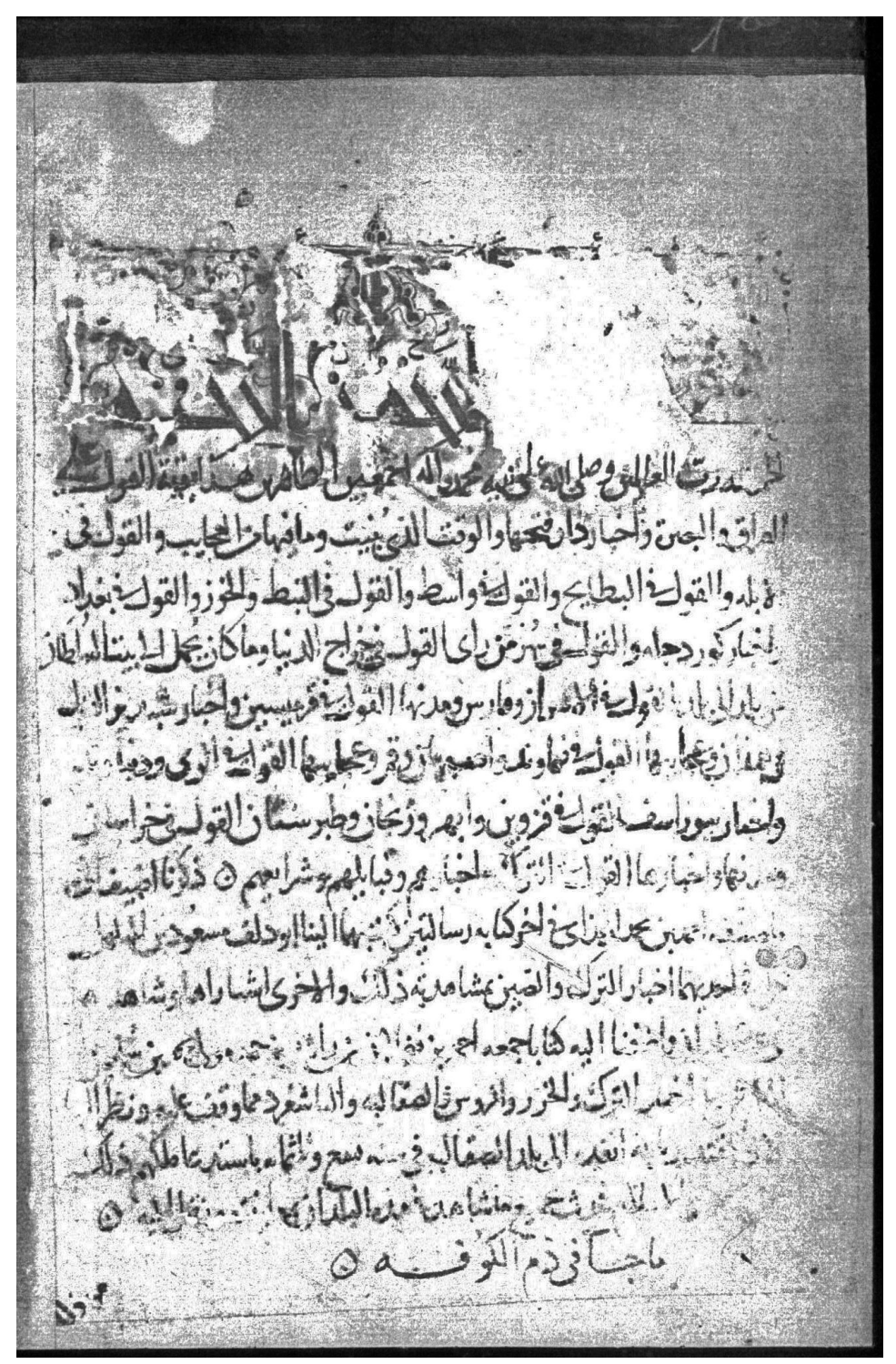

Figure 1: The first folio of the Mashhad manuscript (missing in Sezgin's facsimile edition), which opens with 'Linking passage no. 1' (by permission of the Prussian State Library, Berlin).

95. The only element missing from Abū Dulaf's work is the use of saj`. For the characteristics of the maqāma, see J. Hämeen-Anttila, Maqāma: A History of a Genre (Wiesbaden: Harrassowitz, 2002); C. Brockelmann and C. Pellat, "Makāma," in Encyclopaedia of Islam, 2nd ed. 


\section{Bibliography}

Blair, Sheila. The Monumental Inscriptions from Early Islamic Iran and Transoxiana. Leiden: Brill, 1991.

Bosworth, C. E. The "Lațā'if al-Ma'ārif" of Tha'ālibī: The Book of Curious and Entertaining Information. Edinburgh: Edinburgh University Press, 1968.

---. The Medieval Islamic Underworld: The Banū Sāsān in Arabic Society and Literature. 2 vols. Leiden: Brill, 1976.

---. The Ornament of Histories: A History of the Eastern Islamic Lands AD 650-1041; The Persian Text of Abū Sa'ìd 'Abd al-Hayy Gardīzī. London: I. B. Tauris, 2018.

Brockelmann, C., and C. Pellat. "Maḳāma." In Encyclopaedia of Islam, 2nd edition. Leiden: Brill Online, 2012.

Bulgakov, P. G. Vtoraya zapiska Abu Dulafa. Moscow: Izdatelstvo Vostochnoĭ Literatury, 1960.

Bulliet, R. “Abū Dolaf al-Yanbū'č.” In Encyclopaedia Iranica, online ed. Updated 2011.

Cahen, C., "Ibn al-'Amīd". In Encyclopaedia of Islam, 2nd ed. Leiden: Brill Online, 2012.

Cahen, C., and C. Pellat. "Ibn 'Abbād." In Encyclopaedia of Islam, 2nd ed. Leiden: Brill Online, 2012.

Carey, J., ed. The Faber Book of Reportage. London: Faber, 1989.

Dodge, B., trans. The Fihrist of al-Nadim: A Tenth-Century Survey of Muslim Culture, 2 vols. New York: Columbia University Press, 1970.

Donzel, E. von, and C. Ott. "Yādjūdj wa-mādjūdj." In Encyclopaedia of Islam, 2nd ed. Leiden: Brill Online, 2012.

Ducène, J.-C. L'Europe et les géographes arabes du Moyen Âge. Paris: CNRS Éditions, 2017. Hämeen-Anttila, J. Maqāma: A History of a Genre. Wiesbaden: Harrassowitz, 2002.

Ibn al-Faqīh. Kitāb al-Buldān. 2nd ed. Edited by Y. al-Hādī. Beirut: 'Ālam al-Kutub, 2009. ---. Mukhtașar kitāb al-Buldān. Edited by M. J. de Goeje. Leiden: Brill, 1885.

Ibn Khurradādhbih. Al-Masālik wa-l-mamālik. Edited by M. de Goeje. Leiden: Brill, 1892. Ibn al-Nadīm. Kitāb al-Fihrist. Edited by Ayman Fu'ād Sayyid. London: Mu'assasat al-Furqān li-1-Turāth al-Islāmī, 2009.

Kahle, P. "Islamische Quellen zum chinesischen Porzellan." Zeitschrift der Deutschen Morgenländischen Gesellschaft, n.s., 13 [88] (1934): 1-45. 
Khalidov, A. B. “Ebn al-Faqīh, Abū Bakr Aḥmad." In Encyclopaedia Iranica, online ed. Updated 2011.

Kovalevskiľ, A. P. Kniga Akhmeda ibn-Faḍlāna o ego puteshestvii na Volgu v. 921-922 gg. (stat'i, perevody i kommentarii). Kharkov: Izdatelstvo Gos. Universiteta im. A.M. Gori'kogo, 1956.

Krachkovskiǐ, I. Yu. Puteshestvie Ibn-Faḍlāna na Volgu (perevod i kommentarǐ̃. Moscow: Izdatelstvo Akademii Nauk SSSR, 1939.

-C-."Vtoraya zapiska Abū Dulafa v geograficheskom slovare Iāḳūta (Azerbaǐzhan, Armeniya, Iran)." Izvestiia Akademii Nauk Azerbaizhanskoi SSR 8 (1949): 65-77. Reprinted in Izbrannye sochineniia, edited by V. I. Beliaev and G. V. Tsereteli, 6 vols., 1:280-92. Moscow: Izdatelstvo Akademii Nauk SSSR, 1955.

Madelung, W. "Yahyyā b. Zayd.” In Encyclopaedia of Islam, 2nd ed. Leiden: Brill Online, 2012.

Massé, H., trans. Abrégé du livre du pays. Damascus: Institut français de Damas, 1973.

Minorsky, V. Abū Dulaf Miṣ ‘ar ibn Muhalhil’s Travels in Iran (circa A.D. 950). Cairo: Cairo University Press, 1955.

-_-. "La deuxième risāla d’Abū-Dulaf." Oriens 5, no. 1 (1952): 23-27.

-_- "Tamìm b. Bahrr's Journey to the Uyghurs." Bulletin of the School of Oriental and African Studies 12, no. 2 (1948): 275-305.

Miquel, A. La géographie humaine du monde musulman jusqu'au milieu du 11e siècle. 3 vols. Paris: Éditions de l'EHESS, 2001.

Montgomery, J. E. Al-Jāhiz: In Praise of Books. Edinburgh: Edinburgh University Press, 2013.

-C-. "Ibn Faḍlān and the Rūsiyyah." Journal of Arabic and Islamic Studies 3 (2000): 1-25.

--_. "Mission to the Volga." In Two Arabic Travel Books, edited by P. F. Kennedy and S. M. Toorawa. New York: New York University Press, 2014.

---. "Pyrrhic Scepticism and the Conquest of Disorder: Prolegomenon to the Study of Ibn Faḍlān." In Problems in Arabic Literature, edited by M. Maroth, 43-89. Piliscsaba: Avicenna Institute of Middle East Studies, 2004.

--C. "Serendipity, Resistance and Multivalency: Ibn Khurradādhbih's Kitāb al-Masālik wa-1-Mamālik." In On Fiction and Adab in Medieval Arabic Literature, edited by P. F. Kennedy, 177-230. Wiesbaden: Harrassowitz, 2005.

-C-. "Travelling Autopsies: Ibn Faḍlān and the Bulghār." Middle Eastern Literatures 7, no. 1 (2004): 3-32. 
- - . "Where Is the Real Ibn Faḍlān?" In Muslims on the Volga: Diplomacy and Islam in the Age of Ibn Faḍlān, edited by J. Shepard and W. L. Treadwell. London: I. B. Tauris, forthcoming in 2021.

Pomerantz, M. Licit Magic: The Life and Letters of al-Șāhib b. 'Abbād (d. 385/995). Leiden: Brill, 2018.

Ritter,H. “ZumTextvonIbnFaḍlān'sReisebericht.”ZeitschriftderDeutschenMorgenländischen Gesellschaft 96 (1942): 98-126.

Rohr-Sauer, A. von. Des Abū Dulaf Bericht über seine Reise nach Turkestān, China und Indien: Neu übersetzt und untersucht. Bonn: Bonner Universitäts Buchdruckerei, 1939.

Schoeler, G. The Genesis of Literature in Islam: From the Aural to the Read. Edinburgh: Edinburgh University Press, 2009.

Sezgin, F., et al. eds., Majmū`a fì al-jughrāfiyya: Mimmā allafahu Ibn al-Faqīh wa-Ibn Faḍlān wa-Abū Dulaf al-Khazraj̄i. Frankfurt: Ma'had Ta'rīkh al-'Ulūm al-'Arabiyya wa-l-Islāmiyya, 1987.

Shepard, J., and W. L. Treadwell, eds., Muslims on the Volga: Diplomacy and Islam in the World of Ibn Faḍlān. London: I. B. Tauris, forthcoming in 2021.

Togan, Z. V. Ibn Faḍlān’s Reisebericht. Leipzig: Brockhaus, 1939.

Torgoev, A. I., ed. Puteshestvie Ibn Faḍlāna: Volzhskǐ̌ put' ot Bagdada do Bulgara. Moscow: Dom Mardzhani, 2016.

Treadwell,W.L."The “Abbasid'Mission to the BulghārCourt(309-310/921-922) Reconsidered.” Forthcoming.

-- . A History of the Sāmānids: The First Islamic Dynasty of Central Asia. Edinburgh: Edinburgh University Press, forthcoming in 2021.

-_-. "Ibn Faḍlān and the Mashhad Miscellany." Forthcoming.

Validov (Togan), A. Z. “Meshkhedskaya rukopis' Ibni-l'-Fakikha.” Izvestiia Rossiǐkoř Akademii Nauk (1924): 237-48.

Yāqūt. Mu'jam al-buldān. Beirut: Dār Ṣādir, n.d.

Zadeh, T. Mapping Frontiers across Medieval Islam: Geography, Translation and the 'Abbasid Empire. London: I. B. Tauris, 2017.

-- - 'Of Mummies, Poets and Water Nymphs: Tracing the Codicological Limits of Ibn Khurradādhbih's Geography. In 'Abbāsid Studies 4, edited by M. Bernards, 8-75. Warminster: Gibb Memorial Trust, 2013. 